\title{
Caseobacter polymorphus gen. nov., sp. nov., a Coryneform Bacterium from Cheese
}

\author{
W. H. J. CROMBACH \\ Laboratory of Microbiology, Agricultural University, Wageningen, The Netherlands
}

\begin{abstract}
Morphological and physiological characteristics of 13 non-orange coryneforms isolated from the rinds of soft cheeses were compared with 23 coryneforms (12 soil isolates identified as arthrobacters and 22 activated-sludge isolates). The cheese strains can be differentiated from the arthrobacters mainly by their physiological features, which correlate well with differences in the amino acid and sugar compositions of the cell walls of the two groups of organisms: mesodiaminopimelic acid and arabinose are present in the cell walls of the non-orange cheese coryneforms and lysine and glucose are present in the cell walls of the soil arthrobacters. The non-orange cheese coryneforms contain corynomycolic acids, indicating a certain relationship with corynebacteria. From these and earlier studies on morphology and physiology and from hybridization experiments and deoxyribonucleic acid base composition determinations on the non-orange cheese coryneforms, it is concluded that these organisms belong to a new genus and species, for which the names Caseobacter and C. polymorphus, respectively, are proposed. Strain AC 256 is designated the type strain of C. polymorphus.
\end{abstract}

Non-orange coryneform bacteria showing a pleomorphic morphology constitute an important part of the surface flora of both hard and soft cheeses. Initially, Mulder and Antheunisse (22) classified them as cheese arthrobacters from soil and noted their distinct pleomorphic morphology. However, further investigation (21) revealed that the gray-white cheese coryneforms, as well as the orange cheese coryneforms of the Brevibacterium linens type, deviate from soil arthrobacters with respect to nutritional requirements (particularly concerning nitrogen compounds and vitamins), salt tolerance, and production of polysaccharides. Furthermore, soil arthrobacters metabolize glucose more readily than do the cheese strains. The latter, however, oxidize glucose nearly completely in contrast to the soil arthrobacters, which convert about half of the glucose into reserve material, namely, glycogen. Consequently, Mulder et al. (23) concluded that gray-white cheese coryneforms should not be placed in the genus Arthrobacter, a view supported by the inability of the nonorange cheese coryneforms to decompose both urea and uric acid (3) and by the results of comparative studies on the morphological and physiological properties of both groups of coryneforms (8). The deoxyribonucleic acid (DNA) base compositions of most of the strains in the two groups are in the range of 65 to $67 \mathrm{~mol} \%$ guanine plus cytosine $(\mathrm{G}+\mathrm{C})$, but a low degree $(26 \%)$ of binding was obtained in hybridization experiments between DNA samples from representatives of both groups (7).
The majority of the non-orange cheese strains tested, although isolated from different types of soft cheeses, show a nucleotide-sequence relatedness of more than $86 \%$ (7). Consequently, this group of strains belongs to one genospecies according to the criteria set forth by De Ley (12) and Brenner (5), namely, $70 \%$ or more nucleotide-sequence relatedness and $\mathrm{G}+\mathrm{C}$ values in a narrow range $(6 \%)(6 ; \mathrm{W}$. H. J. Crombach, Ph.D. thesis, Agricultural University, Wageningen, The Netherlands, 1974).

The purpose of the present study was to describe the non-orange cheese coryneforms and to determine their taxonomic niche. Many morphological and physiological characteristics and cell wall compositions of non-orange cheese coryneforms and soil arthrobacters were compared. Eleven coryneforms from activated sludge from dairy waste, organisms that are closely related to soil arthrobacters, were included in the morphological and physiological studies. From the results of this study, as supplemented with previously published data (6-8; Crombach, Ph.D. thesis, Agricultural University, Wageningen, The Netherlands, 1974) on morphology, physiology, DNA base composition, and DNA hybridization, a classification of the non-orange cheese coryneforms is proposed.

\section{MATERIALS AND METHODS}

Bacterial strains. The strains used in this study are listed in Table 1, where they are divided into three groups on the bases of origin and pigmentation. All 
TABLE 1. List of strains studied

\begin{tabular}{|c|c|c|c|}
\hline Microorganism & Strain no. & Color & Origin \\
\hline \multicolumn{4}{|l|}{ Group I (soil arthrobacters) } \\
\hline \multirow[t]{5}{*}{ Arthrobacter simplex } & AC 4 & Gray-white & Acid soil \\
\hline & AC 11 & Gray-white & Alkaline soil \\
\hline & AC 16 & Gray-white & Alkaline soil \\
\hline & $\mathrm{AC} 29$ & Gray-white & Neutral soil \\
\hline & AC 157 & Gray-white & Alkaline soil \\
\hline Arthrobacter sp. & $\mathrm{AC} 1$ & Gray-white & Acid soil \\
\hline \multirow{6}{*}{ Arthrobacter globiformis } & AC 8 & Gray-white & Alkaline soil \\
\hline & AC 158 & Gray-white & Alkaline soil \\
\hline & AC 166 & Gray-white & Acid soil \\
\hline & AC 206 & Gray-white & Dried alkaline soil \\
\hline & AC 403 & Gray-white & $\mathrm{ATCC}^{a} 8602$ \\
\hline & AC 405 & Gray-white & ATCC 8010 \\
\hline \multirow[t]{13}{*}{ Group II (non-orange cheese coryneforms) } & EC 7 & Red & Limburger cheese \\
\hline & EC 9 & Light-red & Limburger cheese \\
\hline & EC 10 & Light-red & Limburger cheese \\
\hline & EC 14 & Gray-white & Limburger cheese \\
\hline & EC 15 & Gray-white & Limburger cheese \\
\hline & EC 16 & Gray-white & Limburger cheese \\
\hline & EC 20 & Gray-white & Limburger cheese \\
\hline & AC 253 & Gray-white & Meshanger cheese \\
\hline & AC 256 & Gray-white & Meshanger cheese \\
\hline & AC 261 & Gray-white & Meshanger cheese \\
\hline & AC 262 & Gray-white & Meshanger cheese \\
\hline & AC 263 & Gray-white & Meshanger cheese \\
\hline & AC 278 & Light-red & Meshanger cheese \\
\hline \multirow[t]{11}{*}{ Group III (water coryneforms) } & AC 766 & Light-yellow & $\begin{array}{l}\text { Dairy waste acti- } \\
\text { vated sludge }{ }^{b} \text { A.D } \\
\text { Adamse }\end{array}$ \\
\hline & AC 793 & Cream & $\begin{array}{l}\text { Dairy waste acti- } \\
\text { vated sludge }{ }^{b} \text { A.D. } \\
\text { Adamse }\end{array}$ \\
\hline & AC 799 & Cream & $\begin{array}{l}\text { Dairy waste acti- } \\
\text { vated sludge, }{ }^{b} \text { A.D } \\
\text { Adamse }\end{array}$ \\
\hline & AC 804 & Cream & $\begin{array}{l}\text { Dairy waste acti- } \\
\text { vated sludge, }{ }^{b} \text { A.D } \\
\text { Adamse }\end{array}$ \\
\hline & AC 807 & Orange & $\begin{array}{l}\text { Dairy waste acti- } \\
\text { vated sludge, }{ }^{b} \text { A.D } \\
\text { Adamse }\end{array}$ \\
\hline & AC 811 & Orange & $\begin{array}{l}\text { Dairy waste acti- } \\
\text { vated sludge, }{ }^{b} \text { A.D } \\
\text { Adamse }\end{array}$ \\
\hline & AC 813 & Orange & $\begin{array}{l}\text { Dairy waste acti- } \\
\text { vated sludge, }{ }^{b} \text { A.D } \\
\text { Adamse }\end{array}$ \\
\hline & AC 814 & Light-yellow & $\begin{array}{l}\text { Dairy waste acti- } \\
\text { vated sludge }{ }^{b} \text { A.D } \\
\text { Adamse }\end{array}$ \\
\hline & AC 820 & Light-yellow & $\begin{array}{l}\text { Dairy waste acti- } \\
\text { vated sludge, }{ }^{b} \text { A.D } \\
\text { Adamse }\end{array}$ \\
\hline & AC 823 & Light-pink & $\begin{array}{l}\text { Dairy waste acti- } \\
\text { vated sludge, }{ }^{b} \text { A.D } \\
\text { Adamse }\end{array}$ \\
\hline & AC 824 & Light-yellow & $\begin{array}{l}\text { Dairy waste acti } \\
\text { vated sludge, }{ }^{b} \text { A.D } \\
\text { Adamse }\end{array}$ \\
\hline
\end{tabular}

${ }^{a}$ Abbreviation: ATCC, American Type Culture Collection, Rockville, Md.

${ }^{b}$ Strains isolated by A.D. Adamse, Laboratory of Microbiology, Agricultural University, Wageningen, The Netherlands. 
tests were performed with active cells less than 1 week old.

Morphology. Colonial and cellular morphologies were determined on agar (Oxoid) $(1.2 \%)$ containing yeast extract (Merck) $(0.7 \%)$ and glucose $(1 \%)$ after 1 week of incubation at $25^{\circ} \mathrm{C}$.

Utilization of sole carbon sources. The following compounds were tested for utilization as sole sources of carbon: fructose, galactose, xylose, cellobiose, maltose, mannitol, inositol, malate, succinate, glyoxylate, and glycerol. The basal medium consisted of yeast extract $(0.2 \%), \quad \mathrm{MgSO}_{4} \cdot 7 \mathrm{H}_{2} \mathrm{O} \quad(0.05 \%), \quad \mathrm{K}_{2} \mathrm{HPO}_{4}$ $(0.01 \%)$, hot-water extract of clay soil $(100 \mathrm{ml})$, and tap water $(900 \mathrm{ml})$; the $\mathrm{pH}$ was adjusted to 7.2 before sterilization by heat. The carbohydrates were autoclaved separately and were added to the sterile basal medium to give a final concentration of $0.5 \%$, with the exception of glyoxylate, which was added to a concentration of only $0.25 \%$ as the higher concentration inhibits growth. A 5-ml volume of medium was inoculated with $0.1 \mathrm{ml}$ of an active cell suspension of about 20 nephelometer (Eel) units and were incubated aerobically for 5 days at $25^{\circ} \mathrm{C}$. Readings were recorded as positive when the turbidity was $50 \%$ over the control and exceeded 50 nephelometer (Eel) units.

Utilization of sole nitrogen sources. Utilization of the amino acids valine, methionine, asparagine, lysine, tyrosine, and tryptophan as sole nitrogen sources was determined in a basal medium composed of: yeast extract (Merck) $(0.01 \%)$, glucose $(0.5 \%)$, $\mathrm{K}_{2} \mathrm{HPO}_{4}(0.1 \%), \mathrm{MgSO}_{4} \cdot 7 \mathrm{H}_{2} \mathrm{O}(0.05 \%)$, hot-water extract of clay soil $(100 \mathrm{ml})$, and tap water $(900 \mathrm{ml})$. The amino acids were added to final concentrations of $0.3 \%$, and the $\mathrm{pH}$ was adjusted to 7.2 before sterilization by heat. $\mathrm{K}_{2} \mathrm{HPO}_{4}$ was autoclaved separately to avoid precipitation. Inoculation, conditions of incubation, and determination of results were the same as for the utilization of sole carbon sources.

Choline and glucosamine as sole carbon and nitrogen sources. The utilization of choline and glucosamine as sole carbon and nitrogen sources was determined in the same medium as used for nitrogen sources except that glucose was omitted. Choline and glucosamine were sterilized separately by Seitz filtration and were added to the medium in amounts sufficient to give a final concentration each of $0.3 \%$. The media were inoculated and incubated as described earlier. A $50 \%$ higher turbidity as compared to the control was considered to be a positive result. Choline decomposition was also tested with the replica technique by which the medium was inoculated by a pinbed from the original plate with the different colonies.

Sensitivity to UV light. A $0.1-\mathrm{ml}$ volume of a cell suspension was spread over the surface of a plated medium containing agar (Oxoid) $(1.2 \%)$, yeast extract (Merck) $(0.7 \%)$, and glucose $(1.0 \%)$. Part of the inoculated plate was immediately exposed to an ultraviolet (UV) light source (Philips, type 90823) for 30 or $60 \mathrm{~s}$ at a distance of $35 \mathrm{~cm}$. Examination of the plates for growth was made after 5 days of incubation at $30^{\circ} \mathrm{C}$.

Susceptibility to tellurite. One-tenth milliliter of a cell suspension was spread over the surface of a plated medium containing nutrient broth (Oxoid) (100 $\mathrm{ml})$, sorbitol $(5 \mathrm{~g})$, glycerol $(10 \mathrm{~g})$, potassium tellurite $(0.4 \mathrm{~g})$, agar $(12 \mathrm{~g})$, and water $(900 \mathrm{ml})$. The appearance of black colonies within 5 days at $25^{\circ} \mathrm{C}$ was an indication of resistance to tellurite.

Susceptibility to dyes. Malachite green, safranin, gentian violet, methylene blue, and bromothymol blue were dissolved in a 1:5 mixture of ethanol and water to yield a concentration of $1 \mathrm{mg} / \mathrm{ml}$. The solutions were sterilized by filtration through a membrane filter (Millipore Corp., 0.45- $\mu \mathrm{m}$ pore size) and were then added to a medium containing yeast extract $(0.7 \%)$, glucose $(1 \%)$, and agar $(1.2 \%)$ to give a final dye concentration of $80 \mu \mathrm{g} / \mathrm{ml}$. The plated media were inoculated by means of the replica technique, incubated at $30^{\circ} \mathrm{C}$, and examined for growth over a period of 2 weeks.

Susceptibility to antibiotics. Disks impregnated with the following antibiotics (Calbiochem) were placed on a solidified, plated medium mixed with 0.5 $\mathrm{ml}$ of a cell suspension: penicillin $\mathrm{G}, 5 \mathrm{U} /$ disk; novobiocin, $5 \mu \mathrm{g} /$ disk; chloramphenicol, $50 \mu \mathrm{g} /$ disk; neomycin, $30 \mu \mathrm{g} /$ disk; erythromycin, $10 \mu \mathrm{g} /$ disk; kanamycin, $30 \mu \mathrm{g} /$ disk; streptomycin, $10 \mu \mathrm{g} /$ disk; and tetracycline, $10 \mu \mathrm{g} /$ disk. Growth was checked after 1 and 2 days of incubation at $25^{\circ} \mathrm{C}$.

Growth in litmus milk. A 5-ml volume of litmus milk was inoculated with $0.1 \mathrm{ml}$ of an active cell suspension of about 20 nephelometer (Eel) units and incubated aerobically at $25^{\circ} \mathrm{C}$. Growth, coagulation of the casein, and change of color were examined several times over a period of 3 weeks.

Survival at $60^{\circ} \mathrm{C}$. Tubes containing $5 \mathrm{ml}$ of a yeast extract $(0.7 \%)$-glucose $(1 \%)$ medium were inoculated with $0.1 \mathrm{ml}$ of an active cell suspension and kept at $60^{\circ} \mathrm{C}$ for $0,4,8,16$, or $32 \mathrm{~min}$, cooled immediately, and incubated aerobically at $25^{\circ} \mathrm{C}$ for 5 days.

Survival in skim milk at $70^{\circ} \mathrm{C}$. A cell suspension in skim milk, which was heated at $70^{\circ} \mathrm{C}$ for $0.5 \mathrm{~h}$, was incubated at $25^{\circ} \mathrm{C}$ in the above-mentioned medium and examined for growth over a period of 2 weeks.

Gas and nitrite production from nitrate. Tubes of nutrient broth supplemented with $1 \%$ glycerol and $1 \% \mathrm{KNO}_{3}$ and provided with Durham tubes were inoculated with $0.1 \mathrm{ml}$ of a dilute cell suspension and incubated anaerobically for up to 2 weeks at $25^{\circ} \mathrm{C}$. The control tubes lacked $\mathrm{KNO}_{3}$. The tubes were examined for gas and nitrite production (reagent of Gries-Romijn [24]).

Hydrolysis of cellulose. Cellulolytic activity was tested in two ways. In the first method, a medium consisting of cellulose (Avicel-SF) $(0.25 \%), \mathrm{K}_{2} \mathrm{HPO}_{4}$ $(0.1 \%), \mathrm{MgSO}_{4} \cdot 7 \mathrm{H}_{2} \mathrm{O}(0.05 \%), \mathrm{NH}_{4} \mathrm{NO}_{3}(0.2 \%)$, yeast extract (Merck) $(0.1 \%)$, and agar $(0.9 \%)$, at a pH of 7.2 , was inoculated with one streak of the microorganism and incubated at $25^{\circ} \mathrm{C}$. The plates were examined for clearing around the streak over a period of 1 month. In the second method, strips of Whatman filter paper no. 4 were placed in tubes with $5 \mathrm{ml}$ of medium containing soil extract $(500 \mathrm{ml})$, yeast extract $(0.1 \%)$, $\begin{array}{llll}\mathrm{K}_{2} \mathrm{HPO}_{4}(0.1 \%), & \mathrm{MgSO}_{4} \cdot 7 \mathrm{H}_{2} \mathrm{O} & (0.05 \%), & \mathrm{NH}_{4} \mathrm{NO}_{3}\end{array}$ $(0.2 \%)$, and tap water $(500 \mathrm{ml})$, at a $\mathrm{pH}$ of 7.2 . The tubes were examined over a period of 1 month for decomposition of the strips at the liquid-air interface.

Hydrolysis of Tween 80. The medium used for determining hydrolysis of Tween 80 contained nutrient broth supplied with Tween $80(10 \mathrm{~g}), \mathrm{CaCl}_{2}(0.1 \mathrm{~g})$, agar $(12 \mathrm{~g})$, and tap water $(1,000 \mathrm{ml})$, at a $\mathrm{pH}$ of 7 . A 
precipitation of calcium oleate crystals in the agar around the streak within 2 weeks at $25^{\circ} \mathrm{C}$ indicated a positive result.

Decomposition of DNA and RNA. Decomposition of DNA and ribonucleic acid (RNA) was tested by the method of Jeffries et al. (16).

Decomposition of uric acid and urea. Decomposition of uric acid and urea was tested by the method of Antheunisse (3).

Production of indole and acetylmethylcarbinol. Production of indole and of acetylmethylcarbinol were determined by O'Meara's modification (26) of the Voges-Proskauer reaction (addition of creatine to the reaction mixture to accelerate the test) and the method described by Skerman (26), respectively.

Composition of cell walls (principal amino acids and amino sugars). The cell walls of the strains tested were isolated and purified by use of a method based upon that of Yamada and Komagata (28). The cells were grown in a medium of yeast extract $(0.7 \%)$ and glucose $(1 \%)$, harvested at the end of the logarithmic growth phase, washed in phosphate buffer $(0.01 \mathrm{M})$, and disintegrated with the aid of a French press at $20,000 \mathrm{lb} / \mathrm{in}^{2}$. This treatment was repeated at least several (generally five) times until microscopic examination revealed that at least $95 \%$ of the cells had been disrupted. The walls were isolated and purified by the method of Yamada and Komagata (28). Subsequently, the walls were hydrolyzed with $6 \mathrm{~N} \mathrm{HCl}$ in a sealed ampoule at $105^{\circ} \mathrm{C}$ for $16 \mathrm{~h}$, and the hydrolysate was filtered through a sintered-glass filter and evaporated until nearly dry. About $50 \mathrm{ml}$ of distilled water was then added, and the solution was evaporated again; this procedure was repeated at least twice. Finally, the evaporated hydrolysate was dissolved in an appropriate volume of a citrate buffer $(\mathrm{pH} 2.2)$, as described by van Egeraat (A. W. S. M. van Egeraat, Ph.D. thesis, Agricultural University, Wageningen, The Netherlands, 1972). The amino acids and amino sugars present in $0.5-\mathrm{ml}$ samples were separated and quantitatively analyzed with an amino acid analyzer (Biocal 200).

The occurrence of either LL-diaminopimelic acid (LL-DAP) or meso-DAP was detected on a one-dimensional descending chromatogram using the solvent system methanol $(160 \mathrm{ml})-10 \mathrm{~N} \mathrm{HCl}(5 \mathrm{ml})$-pyridine $(20 \mathrm{ml})$-distilled water $(35 \mathrm{ml})$. No attempts to detect the isomer DD-DAP were made as it is very uncommon in bacterial cell walls.

Composition of cell walls (principal sugars). The purified cell walls were hydrolyzed with $0.5 \mathrm{M}$ sulfuric acid at $105^{\circ} \mathrm{C}$ for $8 \mathrm{~h}$. The sugar-component analysis was carried out by the method described by Zevenhuizen (30) with the aid of an analytical gas chromatograph (Becker Umgraph-F).

Whole-cell analyses for principal sugars of strains $\mathrm{AC} 166$ and $\mathrm{AC} 405$ were performed by $\mathrm{M}$. P. Lechevalier, New Brunswick, N.J.

Mycolic acids. The presence and composition of the mycolic acids of strains AC 166, AC 405, and AC 256 were determined by $M$. P. Lechevalier, and of strains AC 4, AC 157, AC 158, EC 9, EC 2, AC 253, and AC 263, by M. Goodfellow, Newcastle-upon-Tyne, England, using the whole-organism methanolysis technique $(20)$.

\section{RESULTS}

Morphology. Colonies of the aerobic, nonorange, cheese coryneforms (Table 1, group II) appeared somewhat dry on yeast extract-glucose agar, whereas most of the colonies of the soil arthrobacters were mucoid (Fig. 1). Septa occurred frequently in the cells of non-orange cheese coryneforms but were never observed in the cells of the soil arthrobacters. Palisade arrangement and V-formation (snapping) (Fig. 2) were more frequently observed in cultures of non-orange cheese coryneforms than in those of the soil arthrobacters. From the electron micrograph (Fig. 2), it can be seen that the walls of the cells showing the V-formation are not linked directly at the point of attachment but are probably kept together by some extracellular material. Also, in the dividing cell of strain AC 256 (Fig. 3), there is no direct link between the two daughter cells.

Physiology. (i) Sole carbon sources. Fructose, galactose, and glycerol were utilized by the majority of the strains tested (Table 2). Xylose, cellobiose, maltose, mannitol, and sorbitol were good carbon sources for only the soil and activated-sludge bacteria (Table 2 , groups I and III). Inositol was utilized by half of the soil coryneforms (group I), by most of the activated-sludge strains (group III), and by a minority of the

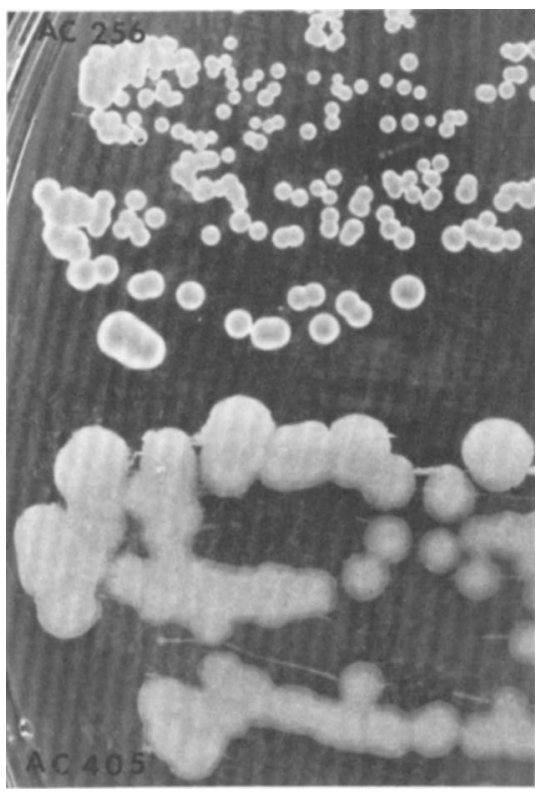

FIG. 1. Two types of colonies produced by the study strains on yeast extract (0.7\%) medium with glucose (1.0\%). (Top) Colonies with a dry appearance (nonorange coryneform strain AC 256); (bottom) colonies with a slimy appearance (Arthrobacter globiformis strain AC 405). Magnification, $\times 2$. 


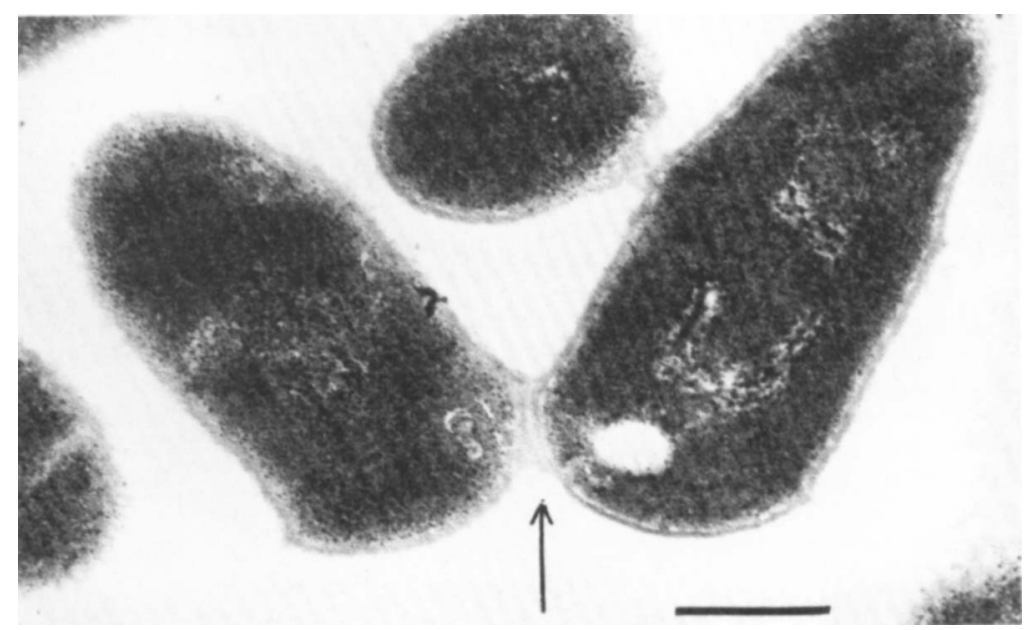

FIG. 2. Electron micrograph of cells of strain AC 256 showing V-formation (snapping division at arrow). The two daughter cells are held together by some extracellular material. Bar represents $0.25 \mu m$.

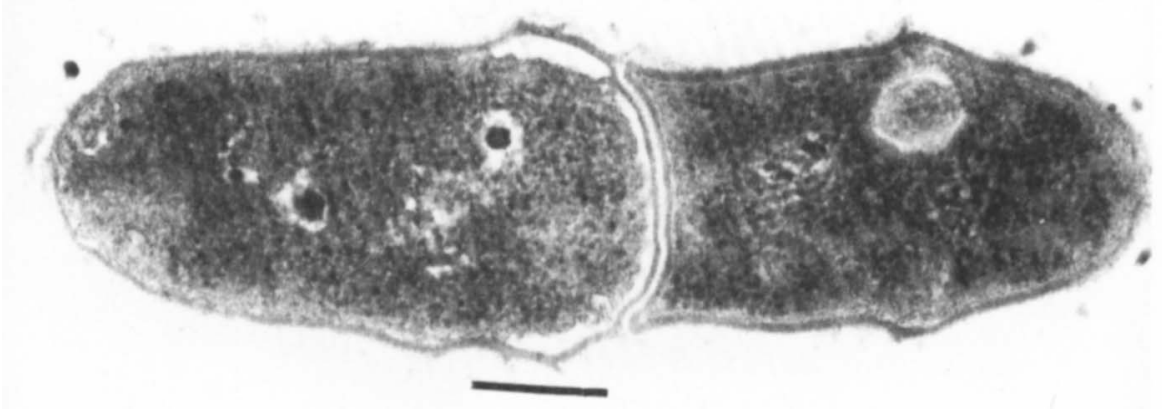

Fig. 3. Electron micrograph of a dividing rod of strain AC 256. No direct link between the cell walls of the two daughter cells can be seen. Bar represents $0.5 \mu \mathrm{m}$.

cheese coryneforms (group II). Malate was a moderately good carbon source for the soil and activated-sludge bacteria, but a poor one for the cheese coryneforms. Succinate was utilized by nearly all of the coryneforms tested; glyoxylate, however, was utilized by only a few arthrobacters.

(ii) Sole nitrogen sources. Valine, tyrosine, lysine, and asparagine were excellent nitrogen sources, but tryptophan was utilized by only about $70 \%$ of the coryneforms tested (Table 2). Methionine was a good nitrogen source for nearly all of the soil and activated-sludge isolates, whereas only half of the cheese coryneforms were able to utilize this amino acid.

(iii) Choline and glucosamine as sole carbon and nitrogen sources. Glucosamine was a good sole carbon and nitrogen source for the Arthrobacter globiformis strains and the bac- teria from activated sludge (see Table 3 , groups I and III). However, only two of five $A$. simplex strains and none of the cheese coryneforms (Table 3, group II) were able to utilize this amino sugar. Choline was utilized by only two soil arthrobacters and by about half of the coryneforms from activated sludge but not by the cheese coryneforms. Very similar results were obtained with the replica technique.

Sensitivity to UV light. The majority of the soil arthrobacters and the coryneforms from activated sludge withstood exposure to UV light for $60 \mathrm{~s}$ fairly well, whereas the cheese coryneforms were more sensitive.

Susceptibility to tellurite. The majority of the coryneforms were inhibited by $0.4 \%$ tellurite supplied to the medium.

Susceptibility to dyes. Safranin, gentian violet, and methylene blue inhibited the growth of 
TABLE 2. Utilization of sole carbon and nitrogen sources by soil arthrobacters, by non-orange coryneforms, and by water coryneforms

\begin{tabular}{|c|c|c|c|c|c|c|c|c|c|c|c|c|c|c|c|c|c|c|c|}
\hline \multirow{3}{*}{ Strain } & \multicolumn{19}{|c|}{ Utilization of: } \\
\hline & \multicolumn{12}{|c|}{ Sole carbon source } & \multicolumn{6}{|c|}{ Sole nitrogen source } & \multirow{2}{*}{ 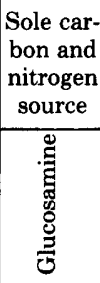 } \\
\hline & 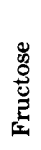 & 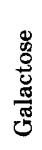 & $\frac{\mathscr{D}}{\grave{2}}$ & 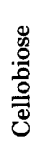 & $\frac{8}{\frac{8}{3}}$ & 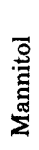 & 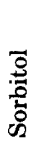 & 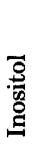 & 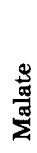 & 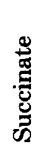 & 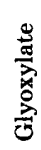 & $\underset{\overparen{D}}{\stackrel{0}{0}}$ & 承 & 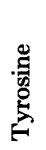 & $\begin{array}{l}\text { 葛 } \\
\text { 尝 }\end{array}$ & 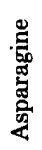 & 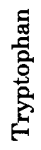 & 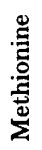 & \\
\hline \multicolumn{20}{|l|}{ Group I } \\
\hline $\mathrm{AC} 4$ & + & + & - & + & + & + & - & - & - & + & + & - & + & + & + & + & + & + & + \\
\hline $\mathrm{AC} 11$ & + & + & + & + & + & + & + & + & + & + & - & + & + & + & + & + & - & + & - \\
\hline $\mathrm{AC} 16$ & + & - & + & - & + & + & - & - & - & + & - & + & - & + & + & + & - & - & - \\
\hline $\mathrm{AC} 29$ & + & + & + & + & + & + & - & - & - & + & - & + & + & + & + & + & + & + & + \\
\hline AC 157 & - & + & + & - & + & + & + & - & + & + & - & + & + & + & + & + & - & + & - \\
\hline $\mathrm{AC} 1$ & + & + & - & + & + & + & - & + & - & + & - & + & + & + & + & + & - & + & + \\
\hline AC 8 & + & + & + & + & + & + & + & - & + & + & - & + & + & + & + & + & + & + & + \\
\hline $\mathrm{AC} 158$ & + & + & + & + & + & + & + & + & + & + & - & + & + & + & + & + & + & + & + \\
\hline AC 166 & + & + & + & + & + & + & + & + & + & + & + & + & + & + & + & + & + & + & + \\
\hline AC 206 & + & + & + & + & + & + & + & - & + & + & - & + & + & + & + & + & + & + & + \\
\hline $\mathrm{AC} 403$ & + & + & + & + & + & + & + & + & + & + & \pm & + & + & + & + & + & + & + & + \\
\hline $\mathrm{AC} 405$ & + & + & + & + & + & + & + & + & + & + & + & + & + & + & + & + & + & + & + \\
\hline \multicolumn{20}{|l|}{ Group II } \\
\hline EC 7 & + & + & - & - & + & + & - & - & - & - & - & + & + & + & + & + & + & + & - \\
\hline EC 9 & + & + & - & + & - & - & - & - & - & + & - & + & + & + & + & + & + & - & - \\
\hline EC 10 & + & + & + & + & + & + & + & + & - & - & - & + & + & + & + & + & - & - & - \\
\hline EC 14 & + & + & + & + & + & + & + & + & - & + & - & + & + & + & + & + & + & + & - \\
\hline EC 15 & + & - & - & - & - & - & - & - & - & + & - & + & + & + & + & + & - & + & - \\
\hline EC 16 & + & + & - & - & - & - & - & - & - & + & - & + & + & + & + & + & + & + & - \\
\hline EC 20 & + & + & + & + & - & - & - & - & - & + & - & + & + & + & + & + & + & + & - \\
\hline AC 253 & + & + & + & + & - & - & - & - & - & + & - & + & + & + & + & + & - & + & - \\
\hline AC 256 & + & + & - & \pm & - & - & - & - & - & + & - & + & + & + & + & + & - & - & - \\
\hline AC 261 & + & + & - & - & - & - & - & - & + & + & - & + & + & + & + & + & + & + & - \\
\hline $\mathrm{AC} 262$ & + & + & - & - & - & - & - & - & - & + & - & + & + & + & + & + & + & - & - \\
\hline AC 263 & + & - & - & - & - & - & - & - & - & + & - & + & + & + & + & + & + & - & - \\
\hline AC 278 & + & - & + & - & - & - & + & + & - & + & - & - & + & + & + & + & + & - & - \\
\hline \multicolumn{20}{|l|}{ Group III } \\
\hline AC 766 & + & + & + & + & + & + & + & + & + & + & - & + & + & + & + & + & + & + & + \\
\hline AC 793 & + & + & + & + & + & + & + & + & - & + & - & + & + & + & + & + & + & + & + \\
\hline AC 799 & + & + & + & + & + & + & + & + & - & + & - & + & + & + & + & + & + & + & + \\
\hline $\mathrm{AC} 804$ & + & + & + & + & + & + & + & + & + & + & - & + & + & + & + & + & + & + & + \\
\hline AC 807 & + & + & + & + & + & + & + & + & + & + & - & + & + & + & + & + & - & - & + \\
\hline AC 811 & + & + & + & + & + & + & + & + & - & + & - & + & + & + & + & + & - & - & - \\
\hline AC 813 & + & + & + & + & + & + & + & - & + & + & - & + & + & + & + & + & - & + & + \\
\hline AC 814 & + & + & + & + & + & + & + & + & + & + & - & + & + & + & + & + & + & + & + \\
\hline AC 820 & + & + & + & + & + & + & + & + & - & \pm & - & + & + & + & + & + & + & + & + \\
\hline AC 823 & + & - & - & - & - & - & + & - & + & + & - & + & + & + & + & + & + & + & + \\
\hline $\mathrm{AC} 824$ & + & + & + & + & + & + & + & - & - & + & - & + & + & + & + & + & + & + & + \\
\hline
\end{tabular}

most of the soil and cheese isolates and of half of the activated-sludge isolates. Malachite green inhibited most of the soil arthrobacters but only half of the coryneforms from cheese and activated sludge. The cheese strains, unlike the soil arthrobacters, were inhibited by bromothymol blue.

Susceptibility to antibiotics. Nearly all of the soil and cheese isolates were inhibited by all of the antibiotics tested. Strain AC 278 was able to grow in the presence of novobiocin and streptomycin.

Penicillin inhibited the growth of 7 and novobiocin inhibited the growth of 5 of the 11 strains from activated sludge. Chloramphenicol, neomycin, kanamycin, and tetracycline inhibited the growth of all of the activated-sludge strains; erythromycin and streptomycin inhibited all except one and two activated-sludge strains, respectively. 
Growth in litmus milk. In general, the reaction produced by the strains was slightly alkaline or neutral. Only two soil arthrobacters, two cheese coryneforms, and four strains from activated sludge coagulated litmus milk within 5 days. Continued incubation for some weeks did not improve the coagulation and production of acid or alkali.

Survival at $60^{\circ} \mathrm{C}$. All of the strains survived heating at $60^{\circ} \mathrm{C}$ for $30 \mathrm{~min}$ in a medium composed of yeast extract $(0.7 \%)$ and glucose $(1 \%)$.

Survival in skim milk at $70^{\circ} \mathrm{C}$. None of the cheese strains, the only group tested, were able to survive in skim milk at $70^{\circ} \mathrm{C}$ for $30 \mathrm{~min}$.

Gas and nitrite production from nitrate. None of the strains produced gas under anaerobic conditions. A minority of the strains showed only a weak nitrite production. Some strains could not be assayed for nitrite production because intermediate products in the medium obviously interfered with color formation.

Hydrolysis of cellulose. The results of the two methods used revealed that none of the strains tested produced extracellular cellulase.

Hydrolysis of Tween 80. Tween 80 was clearly hydrolyzed by only three isolates from both cheese and activated sludge.

Decomposition of DNA and RNA. Both DNA and RNA were decomposed by only three soil arthrobacters and by half of the activatedsludge strains.

Decomposition of uric acid and urea. All except one of the soil arthrobacters and most of the activated-sludge coryneforms degraded uric acid, whereas the non-orange cheese coryneforms did not. Urease was produced by the majority of the isolates from soil and cheese and by all of the activated-sludge strains (Table 3).

Indole and acetylmethylcarbinol production. All of the strains tested for indole and acetylmethylcarbinol production showed a neg. ative result.

Composition of cell walls (principal amino acids and amino sugars). Table 4 shows that, except for strain AC 253, all of the cheese coryneforms contained meso-DAP as their principal basic amino acid whereas the soil arthrobacters contained lysine. Alanine and glutamic acid occurred in significant amounts in the walls of representatives of both groups, and glycine, leucine, aspartic acid, and asparagine were present in less significant amounts in the walls of most strains (Table 4). The walls of all of the strains tested contained muramic acid and glucosamine. Galactosamine was present only in the walls of half of the soil arthrobacters, whereas all of the cheese strains lacked this amino sugar.

Composition of cell walls (principal
TABLE 3. Decomposition of uric acid and urea, the DNA base compositions of the cheese strains, and the degree of binding between the DNA of strain AC 256 and those of the other cheese strains

\begin{tabular}{|c|c|c|c|c|}
\hline \multirow{2}{*}{ Strain no. } & \multicolumn{2}{|c|}{ Decomposition of: } & \multirow{2}{*}{$\begin{array}{c}\text { DNA } \\
\text { base } \\
\text { composi- } \\
\text { tion }^{a} \\
(\mathrm{~mol} \% \\
\mathrm{G}+\mathrm{C})\end{array}$} & \multirow{2}{*}{$\begin{array}{c}\text { Degree of } \\
\text { DNA } \\
\text { binding } \\
\text { with } \\
\text { strain AC } \\
256^{b} \\
\text { (\%) }\end{array}$} \\
\hline & Uric acid & Urea & & \\
\hline
\end{tabular}

\begin{tabular}{|c|c|c|c|c|}
\hline \multicolumn{5}{|l|}{ Group I } \\
\hline $\mathrm{AC} 4$ & + & + & & \\
\hline $\mathrm{AC} 11$ & \pm & + & & \\
\hline $\mathrm{AC} 16$ & - & - & & \\
\hline $\mathrm{AC} 29$ & + & + & & \\
\hline AC 157 & + & - & & \\
\hline $\mathrm{AC} 1$ & + & + & & \\
\hline AC 8 & + & + & & \\
\hline $\mathrm{AC} 158$ & + & + & & \\
\hline AC 166 & + & + & & \\
\hline AC 206 & + & + & & \\
\hline AC 403 & + & + & & \\
\hline $\mathrm{AC} 405$ & + & + & & \\
\hline \multicolumn{5}{|l|}{ Group II } \\
\hline EC 7 & + & - & 65.6 & 16 \\
\hline EC 9 & - & + & 66.3 & 98 \\
\hline EC 10 & - & + & 66.3 & 91 \\
\hline EC 14 & - & - & 56.5 & 26 \\
\hline EC 15 & - & + & 66.7 & 88 \\
\hline $\mathrm{EC} 16$ & - & + & 66.5 & 94 \\
\hline EC 20 & - & - & 60.1 & 24 \\
\hline AC 253 & - & - & 60.6 & 21 \\
\hline AC 256 & - & + & 66.1 & 100 \\
\hline $\mathrm{AC} 261$ & $\mathrm{ND}^{c}$ & + & 66.9 & 91 \\
\hline AC 262 & - & + & 65.5 & 100 \\
\hline AC 263 & - & + & 66.4 & 95 \\
\hline AC 278 & - & - & 66.6 & 86 \\
\hline \multicolumn{5}{|l|}{ Group III } \\
\hline AC 766 & + & + & & \\
\hline AC 793 & + & + & & \\
\hline AC 799 & + & + & & \\
\hline AC 804 & + & + & & \\
\hline AC 807 & - & + & & \\
\hline AC 811 & \pm & + & & \\
\hline $\mathrm{AC} 813$ & - & + & & \\
\hline AC 814 & + & + & & \\
\hline AC 820 & + & + & & \\
\hline AC 823 & + & + & & \\
\hline AC 824 & + & + & & \\
\hline
\end{tabular}

${ }^{a}$ From reference 6 .

${ }^{b}$ From reference 7 .

${ }^{c} \mathrm{ND}$, Not determined.

sugars). The walls of nearly all of the arthrobacters tested contained galactose and glucose (Table 5). Rhamnose and/or mannose occurred only in a minority of the arthrobacters tested (Table 5). Except for strain AC 253, the walls of the cheese strains tested contained arabinose, mannose, and galactose as principal cell wall sugars; glucose was the principal sugar of the walls of cells of strain AC 253 (Table 5). 
TABLE 4. Principal amino acid and principal amino sugar compositions of cell walls of some soil arthrobacters and of non-orange cheese coryneforms

\begin{tabular}{|c|c|c|c|c|c|c|c|c|c|c|c|}
\hline \multirow[b]{2}{*}{ Strain } & \multicolumn{11}{|c|}{ Principal amino acids and principal amino sugars in cell wall } \\
\hline & Alanine & $\begin{array}{l}\text { Glu- } \\
\text { tamic } \\
\text { acid }\end{array}$ & Glycine & Leucine & $\begin{array}{l}\text { Aspar- } \\
\text { tic } \\
\text { acid }\end{array}$ & $\begin{array}{l}\text { Aspara- } \\
\text { gine }\end{array}$ & $\begin{array}{c}\text { meso- } \\
\text { DAP }\end{array}$ & Lysine & $\begin{array}{l}\text { Mur- } \\
\text { amic } \\
\text { acid }\end{array}$ & $\begin{array}{l}\text { Glucos- } \\
\text { amine }\end{array}$ & $\begin{array}{c}\text { Galac- } \\
\text { tosa- } \\
\text { mine }\end{array}$ \\
\hline $\mathrm{AC} 11^{a}$ & $++^{b}$ & + & + & \pm & - & \pm & - & + & + & + & + \\
\hline $\mathrm{AC} 29$ & ++ & + & \pm & \pm & \pm & \pm & - & + & + & ++ & - \\
\hline $\mathrm{AC} 157$ & ++ & + & $\bar{t}$ & \pm & \pm & \pm & - & + & + & + & - \\
\hline $\mathrm{AC} 158$ & ++ & + & \pm & \pm & \pm & \pm & - & + & + & + & \pm \\
\hline $\mathrm{AC} 166$ & $+t$ & + & \pm & \pm & \pm & \pm & - & + & + & + & + \\
\hline AC 206 & ++ & + & \pm & \pm & \pm & \pm & - & + & + & + & - \\
\hline $\mathrm{AC} 405$ & ++ & + & \pm & \pm & \pm & \pm & - & + & + & + & \pm \\
\hline EC 9 & ++ & + & \pm & \pm & \pm & \pm & + & - & + & + & - \\
\hline EC 15 & $+t$ & + & \pm & \pm & \pm & \pm & ++ & - & + & + & - \\
\hline $\mathrm{AC} 253^{c}$ & ++ & ++ & \pm & - & \pm & \pm & - & + & + & ++ & - \\
\hline AC 256 & ++ & + & \pm & \pm & \pm & \pm & + & - & + & + & - \\
\hline $\mathrm{AC} 263$ & ++ & + & \pm & \pm & \pm & \pm & + & - & + & + & - \\
\hline AC 278 & ++ & + & \pm & \pm & \pm & \pm & $+t$ & - & + & + & - \\
\hline
\end{tabular}

${ }^{a}$ Strain AC 11 also contained a compound not yet identified.

${ }^{b}$ Symbols: ++ , high amount present (more than about $30 \%$ of total amount of acid and neutral amino acids); + , moderate amount present (between 10 and $30 \%$ of total amount of acid and neutral amino acids); \pm , low, although detectable, amount present (less than $10 \%$ of total amount of acid and neutral amino acids).

${ }^{c}$ Strain AC 253 also contained a compound not yet identified, probably cisteic acid.

TABLE 5. Principal sugar compositions of cell walls and type of mycolic acid of some soil arthrobacters and non-orange cheese coryneforms

\begin{tabular}{|c|c|c|c|c|c|c|}
\hline \multirow[b]{2}{*}{ Strain } & \multicolumn{6}{|c|}{ Principal cell wall sugars } \\
\hline & $\begin{array}{c}\text { Rham- } \\
\text { nose }\end{array}$ & Arabinose & Mannose & Galactose & Glucose & Mycolic acid \\
\hline \multicolumn{7}{|l|}{ Soil arthrobacter } \\
\hline $\mathrm{AC} 4$ & $\mathrm{ND}^{a}$ & ND & ND & ND & ND & None \\
\hline $\mathrm{AC} 11$ & & & & $++^{b}$ & + & ND \\
\hline $\mathrm{AC} 29$ & ++ & & + & + & & ND \\
\hline $\mathrm{AC} 157$ & ++ & & & ++ & + & None \\
\hline AC 158 & & & & ++ & + & None \\
\hline $\mathrm{AC} 166$ & & & $+^{c}$ & $+^{c}$ & $++^{c}$ & None \\
\hline AC 206 & & & & ++ & + & ND \\
\hline AC 405 & & & $++^{c}$ & $+^{c}$ & $t^{c}$ & None \\
\hline \multicolumn{7}{|c|}{ Non-orange cheese coryneform } \\
\hline EC 9 & & +++ & + & ++ & & Corynomycolic acid \\
\hline EC 15 & & +++ & + & ++ & ND & ND \\
\hline EC 20 & ND & ND & ND & ND & ND & None \\
\hline $\mathrm{AC} 253$ & & & & & +++ & None \\
\hline AC 256 & & $++^{c}$ & + & ++ & & Corynomycolic acid \\
\hline $\mathrm{AC} 263$ & & +++ & ++ & ++ & & Corynomycolic acid \\
\hline $\mathrm{AC} 278$ & & +++ & + & ++ & & ND \\
\hline
\end{tabular}

a Abbreviation: ND, not determined; open spaces denote "not present in detectable amounts."

${ }^{b}$ Symbols:,,++++++ gradation of amounts.

${ }^{c}$ Also detected by M. P. Lechevalier on the basis of whole-cell analysis.

Mycolic acids. Mycolic acids, being of the corynomycolic type, were detected only in the cells of strains EC 9, AC 256, and AC 263 (Table $5)$.

\section{DISCUSSION}

The results of the studies reported here on the morphology and physiology of isolates from soil and dairy waste activated sludge and of non- orange cheese coryneforms can be added to the data derived earlier from similar isolates $(7,8$, 21,22 ). Morphologically, the non-orange cheese coryneforms resemble the soil arthrobacters and the coryneforms from activated sludge in their developmental cycle, although strains in the latter two groups show a more pronounced transformation from rods into cocci and produce more conspicuous germination tubes and less regular, 
longer, and thinner rods (8). Although V-formation was found in representatives of both groups, it occurred more frequently in the cheese strains. This typical arrangement of cells is probably due to the daughter cells being joined at the point of attachment by some residual wall material (Fig. 2). Krulwich and Pate (19) considered this material to be a part of the outer cell wall layer which failed to disrupt during cell division. This phenomenon, called "snapping postfission movement," probably occurs together with the two other mechanisms of $\mathrm{V}$. formation, namely, germination of adjacent cocci and subpolar germination (Crombach, $\mathrm{Ph}$.D. thesis, Agricultural University, Wageningen, The Netherlands, 1966).

The kind of growth on yeast extract-glucose agar demonstrated a clear difference between the soil and the cheese coryneforms (Fig. 1): the latter showed a dry colony form, whereas the former gave a slimy appearance. This difference was also apparent in the ability of the soil arthrobacters, unlike the cheese strains, to produce high amounts of extracellular mucous compounds in addition to significant amounts (60 to $70 \%$ of dry cell matter) of intracellular glycogen (L. P. T. M. Zevenhuizen, Ph.D. thesis, Agricultural University, Wageningen, The Netherlands, 1966). Other important differences between the two groups of coryneforms are the rather frequent occurrence of clearly visible septa in the rods of the cheese strains compared to the soil bacteria and the more pronounced gram-positivity of the former.

Physiological differences between the soil and activated-sludge isolates and those from cheese were noted in the utilization of maltose and mannitol and, to a lesser extent, of sorbitol, inositol, and malate as sole carbon sources (Table 2). Sucrose appeared to be an excellent carbon source for the soil isolates but a poor one for the non-orange cheese coryneforms (8; A. F. M. El-Erian, Ph.D. thesis, Agricultural University, Wageningen, The Netherlands, 1969). Mulder et al. (21) found sucrose to be a moderately good carbon source for the gray-white cheese coryneforms.

The utilization of various amino acids as nitrogen sources revealed no clear differences between the coryneform groups (Table 2). Previous investigations $(1,8,23)$ showed that the coryneforms from soil and activated sludge differ from the non-orange cheese coryneforms in that the former are able to utilize inorganic nitrogen sources whereas the latter, in general, require organic nitrogen sources.

The ability of the soil and activated-sludge isolates to utilize glucosamine as a sole nitrogen and carbon source distinguishes them from the cheese isolates. Furthermore, it is interesting to note that only half of the $A$. simplex strains utilized glucosamine whereas all of the $A$. globiformis strains utilized this compound. This result correlates with the differences found between these two Arthrobacter species in fatty acid composition of the cells (4) and with the results of DNA hybridization experiments (7).

The observed inability of nearly all of 12 soil arthrobacters to utilize choline as a sole carbon and nitrogen source is in disagreement with the results of Kortstee (18), who reported that a great majority of the soil coryneforms, which presumably belong to the genus Arthrobacter, are able to utilize choline as a sole carbon source. A derivative of choline, acetylcholine, was decomposed by a small percentage $(20 \%)$ of the soil arthrobacters studied by Imshenetskii et al. (15).

The ability of the coryneforms from soil and activated sludge to decompose uric acid is another characteristic which distinguishes them from cheese coryneforms. There was no clear difference between the groups of coryneforms studied in their decomposition of urea (Table 3). It should be emphasized that the four cheese strains which differ from the other strains of group II concerning urea decomposition, namely, EC 7, EC 14, EC 20, and AC 253, also differ from the other strains with respect to DNA base composition and DNA-DNA homology $(5,6)$. Using strain AC 256 as a reference, the homology values of the four strains ranged from 16 to $26 \%$, whereas those of the other strains ranged from 86 to $100 \%$ (Table 3).

The result of the tests on uric acid and urea decomposition agree with those of Antheunisse (3), who studied the decomposition of nucleic acid, uric acid, and urea by soil microorganisms including coryneforms and arthrobacters. The soil and cheese coryneforms tested differ in the principal amino acid and amino sugar contents of their cell walls (Table 4). Lysine in the cell walls of the soil arthrobacters seems to substitute for the meso-DAP present in all but one of the cheese coryneforms tested. These two groups of organisms can also be distinguished by the sugar compositions of their cell walls; in particular, the presence of arabinose seems to be a distinguishing characteristic (Table 5). It should be noted that strain AC 253 , which differs from the majority of cheese coryneforms with respect to morphological, physiological, and genetic features (6; Crombach, Ph.D. thesis, Agricultural University, Waginingen, The Netherlands, 1974), also showed amino acid and sugar compositions which differed from those of the other cheese strains. This confirms the results of E. Sharpe, Reading, England (personal com- 
munication), who established the absence of meso-DAP in the cell wall of strain AC 253 and its presence in strain AC 256. Thus the strongly proteolytic gray-white cheese coryneforms studied earlier (21) and represented by strains EC 20 and AC 253 should be considered as a group of bacteria separate from the non-proteolytic cheese coryneforms represented by strain AC 256.

The marked difference in cell wall composition corroborates the conclusion, based on morphological, physiological, and genetic characteristics $(7,21)$, that the non-orange cheese coryneforms are clearly distinct from the soil arthrobacters.

The principal amino acid and sugar composition of the non-orange cheese coryneforms resembles that of diphtheroids, of rapidly growing mycobacteria, and of nocardiae $(9,10)$. Also, the snapping type of cell division (see 29) and the occurrence of corynomycolic acids in the cheese strains tested indicate a relationship with the diphtheroids. However, it is not advisable to place this group of non-orange cheese strains in the genus Corynebacterium, which should only include parasitic and pathogenic diphtheroids of human and other-animal origin. In addition, the cheese strains differ from the diphtheroids by transforming completely, on aging, from rods into cocci, by their high salt ( $8 \%$ or more) tolerance, and by their $\mathrm{G}+\mathrm{C}$ values: about $66 \mathrm{~mol} \%$ for the cheese strains and 57 to $60 \mathrm{~mol} \%$ for the diphtheroids. The large range of $\mathrm{G}+\mathrm{C}$ values (51 to $70 \mathrm{~mol} \%$ ) for the genus Corynebacterium as proposed by Yamada and Komagata (29) is not acceptable, for bacteria which differ by more than $10 \%$ in their $\mathrm{G}+\mathrm{C}$ values can share only a small part of their genomes (13). A relationship between the non-orange cheese strains and the plant-pathogenic corynebacteria with $\mathrm{G}+\mathrm{C}$ values in the range of 65 to $70 \mathrm{~mol} \%$ is improbable given the poor genetic homology (lower than $30 \%$ ) (7) and the differences in the cell wall compositions of these two groups of organisms (most plant pathogens contain rhamnose and ornithine or diaminobutyric acid in their cell walls [25]). It is premature to speculate on a relationship of the cheese strains with the nonpathogenic corynebacteria presented in section III of Bergey's Manual (11). More data are needed before a sharp delineation of these nonpathogens can be made and their relationship with any other group of bacteria can be established.

Although the non-orange cheese strains and the soil arthrobacters show the same DNA base composition, $66 \% \mathrm{G}+\mathrm{C}(6)$, a close relationship is improbable because of (i) differences in their physiologies and cell wall compositions, (ii) the presence of corynomycolic acids in the cheese strains tested, and (iii) the poor genetic homology $(26 \%)$ between representative strains of both groups (7).

A close relationship of the non-orange cheese strains with $B$. linens is not probable because of (i) a small difference (2 to $3 \mathrm{~mol} \%$ ) in their $\mathrm{G}+\mathrm{C}$ values (El-Erian, Ph.D. thesis, Agricultural University, Wageningen, The Netherlands, 1969), (ii) their poor DNA hybridization (11\%) between representative strains of both groups (7), and (iii) differences in morphology, e.g., cell shape, germination of cocci, and less pronounced tendency of $B$. linens to form cocci $(7,21)$. Furthermore, $B$. linens is still more exacting in its amino acid and vitamin requirements and shows a somewhat higher salt tolerance $(8,21)$ than the non-orange strains.

Allocation of the cheese coryneforms to the genus Cellulomonas is not appropriate given the inability of the cheese coryneforms to decompose cellulose and the greater cellular pleomorphism of the cellulomonads.

A relationship of the non-orange cheese coryneforms with the microbacteria is unlikely on account of the distinct differences in their morphologies and thermotolerances.

The non-orange cheese coryneforms are very probably not related to the mycobacteria or nocardiae because of differences in their morphologies and mycolic acid compositions and because of the poor hybridization ( 29 and $32 \%$ ) between the reference strain of the cheese strains, AC 256, and some nocardiae (7). Morphologically and physiologically, the coryneform bacteria isolated from dairy waste activated sludge resemble the soil arthrobacters rather than the cheese coryneforms. This observation agrees with the results of Adamse (1), who found a similarity in physiology and morphology among coryneforms isolated from soil and dairy waste activated sludge. Furthermore, the G+C values of some representative isolates from the activated sludge, being 64 to $67 \%$, are in the same range as for the soil arthrobacters (23). The possibility of a relationship between the cheese coryneforms and the strains of the "rhodochrous complex" is diminished by differences in their mycolic acid compositions: the former contain corynomycolic acids (centered around $\mathrm{C}$ 34 to $\mathrm{C} 36$ ), and the latter contain mycolic acids (ranging from C 34 to $\mathrm{C} 50$ [2]). Furthermore, the data of a numerical taxonomy study (27) suggested that the rhodochrous strains together with Gordona strains constitute a taxon with a physiology comparable to that of genus Nocardia. As nocardiae are clearly different from the cheese strains, a low relatedness between the cheese strains and the rhodochrous strains is 
indirectly indicated. Goodfellow et al. (14), however, concluded from the data of a numerical analysis that rhodochrous strains can be distinguished from members of the genus Nocardia. Furthermore, the cheese strains and the rhodochrous strains differ in morphology (namely, the latter produce, more or less, branches which subsequently fragment), in reduction of nitrate, in utilization of sucrose, maltose, mannitol, and sorbitol, and in habitat.

In conclusion, with respect to morphology, cell wall composition, occurrence of corynomycolic acids, and $\mathrm{G}+\mathrm{C}$ values, the non-orange cheese bacteria, represented by strain AC 256, belong to the "catch-all" group of coryneforms described in part 17 of Bergey's Manual (25). However, differences between these cheese strains and representative strains of the named genera of coryneforms preclude the allocation of the cheese strains to any of the named genera.

Consequently, the cheese strains are here regarded as belonging to a new genus and species, for which the names Caseobacter (L. n. caseus cheese; M. L. masc. $n$. bacter the masculine equivalent of the Gr. neut. n. bactrum a rod; $M$. L. masc.n. Caseobacter cheese rod) and Caseobacter polymorphus $(\mathrm{Gr}$. adj. polymorphus multiform), respectively, are proposed. The type strain of C. polymorphus is AC 256 (our laboratory number), a culture of which has been deposited in the National Collection of Dairy Organisms; National Institute for Research in Dairying, Shinfield, Reading, RG 2 9AT, England, under the number 2097.

Description of Caseobacter gen. nov. Regular rods, 0.8 to 1.2 by 2.0 to $4.0 \mu \mathrm{m}$, are produced on fresh media; branched rods are rarely produced. Rods become ovoid or coccoid with the exhaustion of the medium. After transferring the cocci to a rich medium, they germinate and transform into rods. Cells occur singly, in pairs, and in clusters; palisade formation and V-formation of the cells may occur. Nonmotile. Gram positive or Gram variable. On yeast extract-glucose agar, colonies are small, gray-white, slightly pink or red, with a dry surface. Ammonium salt may be utilized as a sole nitrogen source. Salt is tolerated at high concentrations (up to $12 \%$ ). Aerobic. Oxidase negative. Catalase positive. Deoxyribonuclease and ribonuclease are not produced. Uricase is generally not produced. Urease is frequently produced. DNA base composition: 60 to $67 \mathrm{~mol} \% \mathrm{G}+\mathrm{C}$.

The type species is $C$. polymorphus sp. nov.

Description of $C$. polymorphus sp. nov. Gram-positive, nonmotile rods, 0.8 to 1.2 by 2.0 to $4.0 \mu \mathrm{m}$, which become ovoid or coccoid upon exhaustion of the medium. Most rods are regular and unbranched; a palisade arrangement of the cells occurs frequently. On yeast extract-glucose agar, colonies are small, gray-white, slightly pink or red, and show a dry surface.

The following are frequently utilized as sole sources of carbon: glucose, fructose, galactose, glycerol, lactate, and succinate; xylose, sucrose, maltose, cellobiose, mannitol, sorbitol, inositol, and malate are weakly utilized.

The following are not utilized as sole sources of carbon: lactose, glyoxylate, and citrate.

The following are frequently utilized as sole nitrogen sources: valine, tyrosine, lysine, asparagine, tryptophan, and methionine.

Gelatin, casein, and starch are not hydrolyzed.

Urease is frequently produced.

Uricase is generally not produced.

Aerobic.

Catalase is produced.

Deoxyribonuclease and ribonuclease are not produced.

High concentrations ( 8 to $12 \%$ ) of salt are tolerated.

Tellurite $(0.04 \%)$ frequently inhibits growth.

Nitrites are not produced from nitrates.

Indole and acetylmethylcarbinol are not produced.

DNA base composition: 65.5 to $66.9 \mathrm{~mol} \%$ $\mathrm{G}+\mathrm{C}$.

Cell wall composition: alanine, glutamic acid, meso-DAP, muramic acid, and glucosamine are the characteristic amino acids and amino sugars and arabinose, mannose, and galactose are the characteristic sugars present in the cell walls.

Source: the rind of soft cheese.

Description of the type strain (AC 256). Gram-positive, nonmotile rods, 0.8 to 1.0 by 2.0 to $4.0 \mu \mathrm{m}$, which are ovoid or coccoid, depending on the nutritional conditions. Cocci transferred to fresh media develop into rods; germination tubes are sometimes visible. With progressive exhaustion of the medium, the rods transform into ovoid and then into coccoid cells after about 1 week on yeast extract $(0.7 \%)$ plus glucose $(1 \%)$ at $25^{\circ} \mathrm{C}$. The rods are never branched or irregular. Cells occur singly, in pairs, or in clusters; palisade arrangement and especially V-formation of cells occur frequently. On yeast extract-glucose agar, colonies are rather small, circular, convex, gray-white $(4 \% \mathrm{NaCl}$ in the medium has no effect on the color), and show a rather dry surface.

The following are utilized as sole sources of carbon: glucose, fructose, galactose, glycerol, lactate, acetate, and succinate; maltose and cellobiose are weakly utilized.

The following are not utilized as sole sources of carbon: xylose, lactose, sucrose, mannitol, sorbitol, inositol, citrate, malate, and glyoxylate. Choline and glucosamine are not utilized as sole 
carbon and nitrogen sources.

The following are utilized as sole nitrogen sources: valine, tyrosine, lysine, and asparagine; tryptophan is not utilized.

Gelatin, casein, starch, and pectin are not hydrolyzed.

Tween 80 is weakly hydrolyzed.

Cellulase, deoxyribonuclease, ribonuclease, oxidase, and uricase are not produced.

Catalase and urease are produced. $8 \%$ ).

Salt is tolerated at high concentrations (up to

Growth in litmus milk: after 5 days, weakly alkaline; no coagulation.

Heat resistance: survives at $60^{\circ} \mathrm{C}$ for $32 \mathrm{~min}$; however, this strain does not survive at $70^{\circ} \mathrm{C}$ for 30 min in skim milk.

Withstands UV radiation for $30 \mathrm{~s}$.

Sensitive to $0.04 \%$ of tellurite.

Susceptible to the following antibiotics $(\mathrm{Ox}$ oid): novobiocin, $5 \mu \mathrm{g}$; chloramphenicol, $50 \mu \mathrm{g}$; neomycin, $30 \mu \mathrm{g}$; erythromycin, $10 \mu \mathrm{g}$; kanamycin, $30 \mu \mathrm{g}$; streptomycin, $10 \mu \mathrm{g}$; penicillin $\mathrm{G}, 5 \mathrm{U}$; tetracycline, $10 \mu \mathrm{g}$.

Indole is not produced.

Acetylmethylcarbinol is not produced.

Nitrites are not produced from nitrates.

Aerobic.

Extracellular mucous compounds are not produced in significant amounts.

DNA base composition: $66.1 \mathrm{~mol} \% \mathrm{G}+\mathrm{C}$.

DNA-DNA hybridization experiments revealed only a remote genetic relationship with Corynebacterium flaccumfaciens C 33, C. michiganense C 34, C. tritici C 37, Arthrobacter globiformis ATCC 8010, Brevibacterium linens B 42, and Nocardia sp. AC 86 and AC 555 (6).

Cell wall composition: Alanine, glutamic acid, meso-DAP, and glucosamine are the amino acids and amino sugars and arabinose, galactose, and mannose are the sugars characteristically present in the cell wall. Mycolic acids of the corynomycolic type are present in the cell wall.

Source: the rind of soft cheese.

\section{ACKNOWLEDGMENTS}

I thank M. Goodfellow, Newcastle-upon-Tyne, England, and M. P. Lechevalier, New Brunswick, N.J., for analyzing the mycolic acids of several strains. In particular, I thank $M$. Goodfellow for his critical reading of the manuscript and for helpful advice during its preparation. I also thank Annie Scholten for her technical assistance throughout this study, A.W.S.M. van Egeraat and L.P.T.M. Zevenhuizen for their technical advice, and A. D. Adamse, J. Antheunisse, A. W. S. M. van Egeraat, and E. G. Mulder for reading the manuscript and for valuable discussion.

\section{REPRINT REQUESTS}

Address reprint requests to: Dr. Ir. W. H. J. Crombach, Laboratory of Microbiology, Agricultural University, Wageningen, The Netherlands.

\section{LITERATURE CITED}

1. Adamse, A. D. 1970. Some characteristics of arthrobacters from a dairy waste activated sludge. Water Res. 4:797-803.

2. Alshamaony, L., M. Goodfellow, D. E. Minnikin, and H. Mordarska. 1976. Free mycolic acids as, criteria in the classification of Gordona and the "rhodochrous" complex. J. Gen. Microbiol. 92:183-187.

3. Antheunisse, J. 1972. Decomposition of nucleic acids and some of their degradation products by microorganisms. Antonie van Leeuwenhoek J. Microbiol. Serol. 38:311-327.

4. Bowie, I. S., M. R. Grigor, G. G. Dunckley, M. W. Loutit, and J. S. Loutit. 1972. The DNA base composition and fatty acid constitution of some Gram-positive pleomorphic soil bacteria. Soil Biol. Biochem. 4:397-412.

5. Brenner, D. J. 1973. Deoxyribonucleic acid reassociation in the taxonomy of enteric bacteria. Int. J. Syst. Bacteriol. 23:298-307.

6. Crombach, W. H. J. 1972. DNA base composition of soil arthrobacters and other coryneforms from cheese and sea fish. Antonie van Leeuwenhoek J. Microbiol. Serol. 38:105-120.

7. Crombach, W. H. J. 1974. Relationships among coryneform bacteria from soil, cheese and sea fish. Antonie van Leeuwenhoek J. Microbiol. Serol. 40:347-359.

8. Crombach, W. H. J. 1974. Morphology and physiology of coryneform bacteria. Antonie van Leeuwenhoek J. Microbiol. Serol. 40:361-376.

9. Cummins, C. S., and H. Harris. 1956. The chemical composition of the cell wall in some Gram-positive bacteria and its possible value as taxonomic character. J. Gen. Microbiol. 14:583-600.

10. Cummins, C. S., and H. Harris. 1958. Studies on the cell wall composition and taxonomy of Actinomycetales and related groups. J. Gen. Microbiol. 18:173-189.

11. Cummins, C. S., R. A. Lelliott, and U. A. Rogosa. 1974. Genus I. Corynebacterium, p. 602-617. In R. E. Buchanan and N. E. Gibbons (ed.), Bergey's manual of determinative bacteriology. The Williams \& Wilkins Co., Baltimore.

12. De Ley, J. 1968. Molecular biology and bacterial phylogeny, p. 103-156. In T. Bobzhansky, M. K. Hecht, and W. C. Steere (ed.), Evolutionary biology, vol. 2. Appleton-Century-Crofts, New York.

13. De Ley, J. 1969. Compositional nucleotide distribution and the theoretical prediction of homology in bacterial DNA. J. Theor. Biol. 22:89-116.

14. Goodfellow, M., A. Lind, H. Mordarska, S. Pattyn, and M. Tsukamura. 1974. A co-operative numerical analysis of cultures considered to belong to the "rhodochrous" taxon. J. Gen. Microbiol. 85:291-302.

15. Imshenetskii, A. A., L. S. Popova, and N. F. Kirillova. 1974. Acetylcholine-decomposing microorganisms. Mikrobiologiya 43:986-991.

16. Jeffries, C. D., D. F. Holtman, and D. G. Guse. 1957 Rapid method for determining the activity of microorganisms on nucleic acids. J. Bacteriol. 73:590-591.

17. Keddie, R. M., B. G. S. Leask, and J. M. Grainger. 1966. A comparison of coryneform bacteria from soil and herbage: cell wall composition and nutrition. J. Appl. Bacteriol. 29:17-43.

18. Kortstee, G. J. J. 1970. The aerobic decomposition of choline by microorganisms. Arch. Mikrobiol. 71:235-244.

19. Krulwich, T. A., and J. L. Pate. 1971. Ultrastructural explanation for snapping postfission movements in $\mathrm{Ar}$. throbacter crystallopoietes. J. Bacteriol. 105:408-412.

20. Minnikin, D. E., L. Alshamaony, and M. Goodfellow. 1975. Differentiation of Mycobacterium, Nocardia and related taxa by thin layer chromatographic analysis of 
whole organism methanolysates. J. Gen. Microbiol. 88:200-204.

21. Mulder, E. G., A. D. Adamse, J. Antheunisse, M. H. Deinema, J. W. Woldendorp, and L. P. T. M. Zevenhuizen. 1966. Relationship between Brevibacterium linens and bacteria of the genus Arthrobacter. J. Appl. Bacteriol. 29:44-71.

22. Mulder, E. G., and J. Antheunisse. 1963. Morphologie, physiologie et écologie des Arthrobacter. Ann. Inst. Pasteur (Paris) 105:46-74.

23. Mulder, E. G., J. Antheunisse, and W. H. J. Crombach. 1971. Microbial aspects of pollution in the food and dairy industries, p. 71-89. In G. Sykes and F. A. Skinner (ed.), Microbial aspects of pollution. Academic Press Inc., New York.

24. Netherlands Norm., 323563. 1972. Test methods for waste water. Nederlands Normalisatie Instituut, The Netherlands.

25. Rogosa, M., C. S. Cummins, R. A. Lelliott, and R. M. . Keddie. 1974. Coryneform group of bacteria, p.
599-602. In R. E. Buchanan and N. E. Gibbons (ed.), Bergey's manual of determinative bacteriology. The Williams \& Wilkins Co., Baltimore.

26. Skerman, V. B. D. 1967. A guide to the identification of the genera of bacteria, p. 252, 271. The Williams \& Wilkins Co., Baltimore.

27. Tsukamura, M. 1975. Numerical analysis of the relationship between Mycobacterium, rhodochrous group, and Nocardia by use of hypothetical median organisms. Int. J. Syst. Baceriol. 25:329-335.

28. Yamada, K., and K. Komagata. 1970. Taxonomic studies on coryneform bacteria. 2. Principal amino acids in the cell wall and their taxonomic significance. J. Gen. Appl. Microbiol. 16:103-113.

29. Yamada, K., and K. Komagata. 1972. Taxonomic studies on coryneform bacteria. V. Classification of coryneform bacteria. J. Gen. Appl. Microbiol. 18:417-431.

30. Zevenhuizen, L. P. T. M. 1973. Methylation analysis of acidic exopolysaccharides of Rhizobium and Agrobacterium. Carbohydr. Res. 26:409-419. 